\author{
KATARZYNA WASAK ${ }^{*}$, MAREK DREWNIK ${ }^{2}$ \\ ${ }^{1}$ Polish Academy of Sciences, Institute of Geography and Spatial Organization, Department of Geoenvironmental Research \\ ul. Św. Jana 22, 31-018 Kraków, Poland \\ ${ }^{2}$ Jagiellonian University, Institute of Geography and Spatial Management, Department of Pedology and Soil Geography \\ ul. Gronostajowa 7, 30-387 Kraków, Poland
}

\title{
Sequestration of organic carbon in rendzinas - a review
}

\begin{abstract}
The article refers to the stock and sequestration of organic carbon in soils rich in carbonates, particularly in rendzinas. It presents factors determining sequestration of organic carbon in rendzinas in comparison to other soils, and describes the mechanisms of accumulation of organic matter in these soils. Attention was paid to the atypical morphology of organic and humus horizons occurring in soils rich in carbonates, with specificity related to biological processes.
\end{abstract}

Keywords: Organic carbon sequestration, Rendzinas, Calcisols, Calcium, Magnesium

\section{INTRODUCTION}

Higher content of organic matter was observed in soils developed from weathered rocks rich in calcium carbonate than in other soils under comparable climate conditions with the same vegetation and land use (among others Dobrzański and Turski 1972, Kuźnicki and Skłodowski 1973, Niemyska-Łukaszuk 1977a, Duchaufour 1982, Shang and Tiessen 2003, Ahmed et al. 2012, Wasak and Drewnik 2015, Yang et al. 2016, Wasak 2017). In research covering more than 1800 soil profiles from the entire territory of Germany, Grüneberg et al. (2014) confirmed the higher content of organic matter in soil rich in carbonates both for plains and uplands, and for mountainous areas (Table 1). Even if higher concentration of organic carbon (OC) was recorded in soils neighbouring the rendzinas, the stock of $\mathrm{OC}$ in rendzinas was higher due to thicker humus horizons (Drewnik 1998, Samonil 2007, Wasak 2017). Also the analysis of the morphology of organic and humus horizons and their classification showed that rendzinas contain specific humus forms absent in other soils (Kubiena 1953, Miechówka 2002, Ponge et al. 2011, Jabiol et al. 2013, Zanella et al. 2018a, 2018b). The observations suggest that organic matter transformations in soils rich in calcium carbonate occur in a specific way, and therefore specific sequestration of OC can be expected in such soils.

In modern times, when one of the leading topics in environmental studies in the world is research on sequestration, transformations and accumulation of OC in soils in the context of climatic changes (Lal
2004), the problem of the effect of the mineral part of soil on the biotic part is subject to a broad discussion. Carbonate soils constitute approximately $12 \%$ of soil resources in the world (FAO 1996). Considering a high potential of accumulation of organic carbon, this makes them a very interesting research subject. Processes of transformations of soil organic matter in carbonate soils are still insufficiently investigated both in terms of quantitative sequestration of $\mathrm{OC}$ in the form of humic substances, and understanding of the mechanisms of binding organic matter supplied to the soil on different levels of spatial and functional organisation (Ponge et al. 2011, Wasak 2017).

The objective of this paper is a general presentation, based on review of published data, of the specifics of sequestration of $\mathrm{OC}$ in rendzinas. It also refers to soils rich in calcium carbonate characteristic of dry climate.

\section{FACTORS DETERMINING OC SEQUESTRATION IN RENDZINAS}

Many factors determine the quantity and quality of soil organic matter in soils, and therefore also the stock and sequestration of OC. In rendzinas, the issue was analysed among others in terms of properties of the parent material of the soil, effect of climatic conditions, effect of vegetation and land use, and passage of time.

The effect of the parent material of rendzinas on OC sequestration is manifested in comparative studies considering the degree of weathering and type of rocks the weathered material of which constitutes the soil's parent material. In the territory of Poland, Dobrzański 
and Turski (1972) evidenced that OC concentration in rendzinas in the Lublin Upland is the highest in soils developed from soft rocks rich in carbonates, and the lowest in soils developed on decalcified opokas. Kowaliński and Licznar (1986) found that chernozemic/humic rendzinas developed from cretaceous limestones are characterised by higher concentration of OC than brown rendzinas developed from marls and Trias limestones (Table 1). In this context, it is worth paying attention to the issue of the effect of admixture of non-carbonate siliceous material (aeolian or slope material) often observed in rendzinas on OC sequestration in the soils. In the research on various soils occurring on carbonate bedrock in Bohemian Karst, Šmonil (2007) found that in the conditions of low content of carbonates in the soils resulting from an admixture of non-calcareous material in the uppermost part, lower OC concentration and lower thickness of humus horizons are observed in comparison to rendzinas without admixture of non-calcareous material (Table 1). Similar conclusions were drawn by Shang and Tiessen (2003), investigating soils on the Yucatan Peninsula (Mexico). They determined that the concentration and stock of organic carbon is higher in shallow rendzinas containing more than $30 \%$ of carbonates than in deep red rendzinas containing less than $20 \%$ of carbonates (Table 2 ).

Irrespective of the simple dependency between the content of carbonates in the parent material and OC stock in the soil described above, the issue is investigated more thoroughly in the context of contents of exchangeable $\mathrm{Ca}$ and $\mathrm{Mg}$ in the soil or content of active carbonates (Kowaliński and Licznar 1986, Andreux 1996, Shang and Tiessen 2003, Yang et al. 2016). For example, in the already mentioned research by Kowaliński and Licznar (1986), the authors determined that the concentration of $\mathrm{OC}$ is positively correlated with the content of active carbonates in the soil, and Yang et al. (2016) evidenced that the stock and concentration of OC are positively correlated with the content of exchangeable $\mathrm{Ca}$ and $\mathrm{Mg}$ in rendzinas occurring in South China. Similarly, in rendzinas from the Yucatan (Shang and Tiessen 2003), a positive correlation was determined between the concentration and stock of OC and content of exchangeable $\mathrm{Ca}$.

At the global scale, the most important factor determining $\mathrm{OC}$ sequestration in soils is the variability of climatic conditions, and particularly temperature and humidity (Jobbágy and Jackson 2000, Davidson and Janssens 2006, Tarnocai et al. 2009, Baritz et al. 2010, Ponge et al. 2011). They indirectly affect organic matter supply to the soil (conditioning the specific vegetation), and (directly and indirectly) determine the rate and direction of its transformation (Davidson and Janssens 2006, Kurz-Besson et al. 2006). In mountainous areas, climatic differences determine the variability of OC stock as well as humus forms and forms of organic matter (contribution of particulate organic matter) in soils in particular altitudinal zones (Kubiena 1953, Skiba 1995, Drewnik 2006, Leifeld and Kögel-Knabner 2005, Budge et al. 2010, Bojko and Kabała 2016). At the local scale, microand topoclimatic conditions can cause variability of biological activity in the soil, consequently determining the microvariability of the OC stock in the soil, e.g. on slopes with different expositions (Kim 2000, Withlington and Stanford 2007, Drewnik et al. 2016a).

In the case of soils containing carbonates, the highest concentration and OC stock is observed in areas with high precipitation (favouring the development of vegetation) and simultaneous limiting the biological activity of the soil. It is typical of mountainous areas at moderate latitudes, and particularly the subalpine zone and high concentration and stock of OC in rendzinas under such climate conditions were determined e.g. by Wasak and Drewnik (2015) in the Tatra Mountains, and Grüneberg et al. (2014) in the Alps (Table 1). Very low concentration and stock of OC is characteristic of soils under dry climate. This results from extremely low biomass production (Cunliffe et al. 2016) (Table 1).

A very important factor determining OC sequestration in rendzinas is - similarly as in the other soils - vegetation and land use (Guo and Gifford 2002, Smal and Olszewska 2008, Gonet et al. 2009, Laganiére et al. 2010, Llorente et al. 2010, Ahmed et al. 2012, Wasak and Drewnik 2015, Yang et al. 2016, Cunliffe et al. 2016). Many studies (e.g. Kuźnicki and Skłodowski 1968, 1976, Guo and Gifford 2002, Gonet et al. 2009, Laganiére et al. 2010, Llorente et al. 2010, Ahmed et al. 2012, Yang et al. 2016) showed that the stock of OC in arable soils is lower than in respective forest or grassland soils (Table 2). Afforestation of arable land, however, is often related to a temporary increase in OC stock in the soil, as well as a change in its distribution in soil horizons: higher OC concentration occurs in the surface horizons, and lower - in deeper soil horizons in comparison to arable soils. Time that passed from the moment of change of land use is an important factor here (Smal and Olszewska 2008). The difference in OC stock between forest and arable soils is variable (sometimes higher OC stock is observed in the soils of grasslands, and sometimes in forest soils). This probably depends on the local conditions (Table 2) (Laganiére et al. 2010, Ahmed et al. 2012, Wasak and Drewnik 2015, Yang et al. 2016). Vegetation also has 
TABLE 1. OC concentration in the uppermost part of mineral soil (A horizon) regarding parent material

\begin{tabular}{|c|c|c|c|}
\hline Soil & Parent material & $\begin{array}{l}\text { Soil Organic Carbon } \\
\text { concentration }\left[\mathrm{g} \mathrm{kg}^{-1}\right] \\
\text { (Number of replicates, } \\
\text { Depth / horizon) }\end{array}$ & $\begin{array}{l}\text { Study area / Reference / } \\
\text { method of OC determination }\end{array}$ \\
\hline \multicolumn{4}{|l|}{ FOREST } \\
\hline $\begin{array}{l}\text { Leptosols, Cambisols } \\
\text { (Lowlands) }\end{array}$ & $\begin{array}{l}\text { Shallow soils, slope deposits over } \\
\text { limestone, marlstone and dolomite }\end{array}$ & $\begin{array}{l}62.6 \\
(\mathrm{~N}=108,0-5 \mathrm{~cm})\end{array}$ & \multirow{5}{*}{$\begin{array}{l}\text { Germany / Grünberg et al., } \\
2014 \text { / rapid dichromate } \\
\text { oxidation + gas chromatography }\end{array}$} \\
\hline $\begin{array}{l}\text { Regosols, Arenosols, Podzols } \\
\text { (Lowlands) }\end{array}$ & $\begin{array}{l}\text { Dystrophic sand deposits, } \\
\text { sandy to loamy deposits }\end{array}$ & $\begin{array}{l}33.0 \\
(\mathrm{~N}=205,0-5 \mathrm{~cm})\end{array}$ & \\
\hline $\begin{array}{l}\text { Cambisols, Luvisols, Regosols, } \\
\text { Podzoluvisols (Lowlands) }\end{array}$ & Boulder clay and tills & $\begin{array}{l}44.3 \\
(\mathrm{~N}=93,0-5 \mathrm{~cm})\end{array}$ & \\
\hline $\begin{array}{l}\text { Leptosols, Cambisols } \\
\text { (Mountains) }\end{array}$ & Mostly limestone and dolomite & $\begin{array}{l}108.6 \\
(\mathrm{~N}=18,0-5 \mathrm{~cm})\end{array}$ & \\
\hline $\begin{array}{l}\text { Cambisols, } \\
\text { Podzols (Mountains) }\end{array}$ & $\begin{array}{l}\text { Argillaceaus and silty slates } \\
\text { with greywacke, sandstone, } \\
\text { quarcite and phyllite }\end{array}$ & $\begin{array}{l}58.2 \\
(\mathrm{~N}=252,0-5 \mathrm{~cm})\end{array}$ & \\
\hline $\begin{array}{l}\text { Folic Rendzic Leptosols / } \\
\text { Regosols* }\end{array}$ & Triassic dolomitic limestone & $\begin{array}{l}108.3-134.0 \\
(\mathrm{~N}=2, \mathrm{~A})\end{array}$ & \multirow{3}{*}{$\begin{array}{l}\text { Tatra Mts. (Poland) / } \\
\text { Niemyska-Łukaszuk, } 1977 \text { / } \\
\text { rapid dichromate oxidation }\end{array}$} \\
\hline Eutric Cambisols* & Clay shale with sandstone & $\begin{array}{l}25.8-82.0 \\
(\mathrm{~N}=8, \mathrm{~A})\end{array}$ & \\
\hline Podzols* & Granitoides & $\begin{array}{l}63.8-142.3 \\
(\mathrm{~N}=4, \mathrm{~A})\end{array}$ & \\
\hline Rendzic Leptosols* & \multirow[t]{3}{*}{ Limestone, dolomite, marl } & $\begin{array}{l}55-75 \\
(\mathrm{~N}=29, \mathrm{~A})\end{array}$ & \multirow{5}{*}{$\begin{array}{l}\text { Tatra Mts. (Poland) / } \\
\text { Komornicki, } 1977 \text { / rapid } \\
\text { dichromate oxidation }\end{array}$} \\
\hline Calcaric Leptosols / Regosols* & & $\begin{array}{l}90-100 \\
(\mathrm{~N}=6, \mathrm{~A})\end{array}$ & \\
\hline $\begin{array}{l}\text { Humic Rendzic / Calcaric } \\
\text { Regosols* }\end{array}$ & & $\begin{array}{l}104 \\
(\mathrm{~N}=6, \mathrm{~A})\end{array}$ & \\
\hline $\begin{array}{l}\text { Folic Rendzic Leptosols / } \\
\text { Regosols* }\end{array}$ & \multirow[t]{2}{*}{$\begin{array}{l}\text { Limestone with non-calcareous } \\
\text { material admixture }\end{array}$} & $\begin{array}{l}73-76 \\
(\mathrm{~N}=119, \mathrm{~A})\end{array}$ & \\
\hline Calcaric Cambisols* & & $\begin{array}{l}80-85 \\
(\mathrm{~N}=141, \mathrm{~A})\end{array}$ & \\
\hline Rendzic Leptosol & Limestone & $\begin{array}{l}45.9 \\
(\mathrm{~A}, 50 \mathrm{~cm})\end{array}$ & \multirow{3}{*}{$\begin{array}{l}\text { Bohemia Karst (Czech Rep.) / } \\
\text { Šamonil, } 2007 \text { / rapid } \\
\text { dichromate oxidation }\end{array}$} \\
\hline Calcaric Cambisols & Marl slates & $\begin{array}{l}34.9 \\
(\mathrm{~A}, 0-9 \mathrm{~cm})\end{array}$ & \\
\hline Luvic Cambisol & Siltstones and gravel sands & $\begin{array}{l}29.4 \\
(\mathrm{~A}, 0-6 \mathrm{~cm})\end{array}$ & \\
\hline \multicolumn{4}{|l|}{ ARABLE LAND } \\
\hline Rendzic Phaeozems* & Cretaceous limestone & $\begin{array}{l}18.2 ; 22.3 \\
(\mathrm{~N}=2, \mathrm{~A})\end{array}$ & \multirow{2}{*}{$\begin{array}{l}\text { SW Poland / Kowaliński, } \\
\text { Licznar, } 1986 \text { / rapid } \\
\text { dichromate oxidation }\end{array}$} \\
\hline Calcaric/Dolomitic Cambisols* & Triassic marl, Triassic limestone & $\begin{array}{l}14.8 ; 7.9 \\
(\mathrm{~N}=2, \mathrm{~A})\end{array}$ & \\
\hline Rendzic Paheozems* & Marl, limestones, chalk & $\begin{array}{l}11.09-35.30 \\
(\mathrm{~N}=17, \mathrm{~A})\end{array}$ & \multirow{3}{*}{$\begin{array}{l}\text { SE Poland / Dobrzański and } \\
\text { Turski, } 1976 \text { / rapid dichromate } \\
\text { oxidation }\end{array}$} \\
\hline Rendzic Phaeozems* & Chalk, marl & $\begin{array}{l}8.35-27.12 \\
(\mathrm{~N}=23, \mathrm{~A})\end{array}$ & \\
\hline $\begin{array}{l}\text { Eutric Cambisols, } \\
\text { Eutric Luvisol* }\end{array}$ & Siliceous rocks & $\begin{array}{l}5.26-15.48 \\
(\mathrm{~N}=22, \mathrm{~A})\end{array}$ & \\
\hline
\end{tabular}

* the nearest equivalent in WRB 2015 is given. 
TABLE 2. OC concentration and stock regarding vegetation and land-use

\begin{tabular}{|c|c|c|c|c|c|}
\hline \multirow[t]{2}{*}{$\begin{array}{l}\text { Study } \\
\text { area / study site }\end{array}$} & \multirow[t]{2}{*}{ Soil } & \multirow[t]{2}{*}{ Vegetation / land use } & \multicolumn{2}{|c|}{$\begin{array}{l}\text { Soil Organic Carbon (Number of replicates, } \\
\text { horizon, depth) }\end{array}$} & \multirow{2}{*}{$\begin{array}{l}\text { Reference / } \\
\text { method } \\
\text { of OC } \\
\text { determination }\end{array}$} \\
\hline & & & $\begin{array}{l}\text { Concentration } \\
\text { in A horizon }\left[\mathrm{g} \cdot \mathrm{kg}^{-1}\right]\end{array}$ & 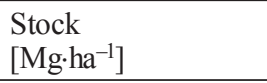 & \\
\hline \multirow{3}{*}{$\begin{array}{l}\text { Silica Plateau } \\
\text { (Slovakia), } \\
\text { MAT: } 5.7-8.5^{\circ} \mathrm{C} \text {, } \\
\text { MAP } 630-990 \\
\text { mm }\end{array}$} & \multirow{3}{*}{$\begin{array}{l}\text { Chromic } \\
\text { Rendzic } \\
\text { Leptosols, } \\
\text { Chromic } \\
\text { Cambisols }\end{array}$} & $\begin{array}{l}\text { Arable land } \\
\text { (since at least 1780) }\end{array}$ & $\begin{array}{l}26 \\
(\mathrm{~N}=13,0-60 \mathrm{~cm})\end{array}$ & $\begin{array}{l}239.7 \\
(\mathrm{~N}=6, \mathrm{~A}, 0-60 \mathrm{~cm})\end{array}$ & \multirow{3}{*}{$\begin{array}{l}\text { Ahmed et al., } \\
2012 \text { / rapid } \\
\text { - dichromate } \\
\text { oxidation + gas } \\
\text {-chromatography }\end{array}$} \\
\hline & & $\begin{array}{l}\text { Forest (since at least } \\
1780 \text { ) }\end{array}$ & $\begin{array}{l}40 \\
(\mathrm{~N}=61,0-60 \mathrm{~cm})\end{array}$ & $\begin{array}{l}307.4 \\
(\mathrm{~N}=5, \mathrm{~A}, 0-60 \mathrm{~cm})\end{array}$ & \\
\hline & & $\begin{array}{l}\text { Pastureland } \\
\text { (since } \sim 1880 \text { ) }\end{array}$ & $\begin{array}{l}41 \\
(\mathrm{~N}=30,0-60 \mathrm{~cm})\end{array}$ & $\begin{array}{l}313.5 \\
(\mathrm{~N}=6, \mathrm{~A}, 0-60 \mathrm{~cm})\end{array}$ & \\
\hline \multirow{3}{*}{$\begin{array}{l}\text { Tatra Mts. } \\
\text { (Poland), } \\
\text { MAT } 2.4^{\circ} \mathrm{C}, \\
\text { MAP } 1,660 \mathrm{~mm} \\
\text { (soils of abandoned } \\
\text { pastureland, ca } 50 \\
\text { years after } \\
\text { abandonment) }\end{array}$} & $\begin{array}{l}\text { Rendzic } \\
\text { Hyper-skeletic } \\
\text { Leptosol }\end{array}$ & $\begin{array}{l}\text { High mountain } \\
\text { calcareous grassland }\end{array}$ & $\begin{array}{l}62.0 \\
(\mathrm{~N}=-9, \mathrm{~A}, 0-15 \mathrm{~cm})\end{array}$ & $\begin{array}{l}47.5 \\
(\mathrm{~N}=9,0-35 \mathrm{~cm}\end{array}$ & \multirow{3}{*}{$\begin{array}{l}\text { Wasak and } \\
\text { Drewnik, } 2015 \text { / } \\
\text { gas } \\
\text { chromatography }\end{array}$} \\
\hline & & $\begin{array}{l}\text { Sparse larch forest } \\
\text { with a dense cover } \\
\text { of grass Calamagrostis }\end{array}$ & $\begin{array}{l}53.3 \\
(\mathrm{~N}=9, \mathrm{~A}, 2-12 \mathrm{~cm})\end{array}$ & $\begin{array}{l}63.5 \\
(\mathrm{~N}=9,0-35 \mathrm{~cm})\end{array}$ & \\
\hline & $\begin{array}{l}\text { Folic Hyper- } \\
\text { skeletic Leptosol }\end{array}$ & Dwarf pine shrubs & $\begin{array}{l}79.9 \\
(\mathrm{~N}=9, \mathrm{~A}, 20-25 \mathrm{~cm})\end{array}$ & $\begin{array}{l}42.9 \\
(\mathrm{~N}=9,0-35 \mathrm{~cm})\end{array}$ & \\
\hline \multirow[t]{2}{*}{$\begin{array}{l}\text { Swiętokrzyskie } \\
\text { Mts. (Poland) }\end{array}$} & $\begin{array}{l}\text { Rendzic } \\
\text { Leptosol* }\end{array}$ & Grassland & $\begin{array}{l}14.1-38.4 \\
(\mathrm{~N}=3, \mathrm{~A}, 0-15 \mathrm{~cm})\end{array}$ & n.a.** & \multirow{2}{*}{$\begin{array}{l}\text { Kowaliński and } \\
\text { Licznar, } 1976 \text { / } \\
\text { rapid dichromate } \\
\text { oxidation }\end{array}$} \\
\hline & $\begin{array}{l}\text { Rendzic } \\
\text { Leptosol* }\end{array}$ & Forest & $\begin{array}{l}73.0 \\
(\mathrm{~N}=1, \mathrm{~A}, 0-2 \mathrm{~cm})\end{array}$ & n.a. & \\
\hline \multirow{4}{*}{$\begin{array}{l}\text { Yucatan (Mexico), } \\
\text { MAT } 26^{\circ} \mathrm{C} \text {, } \\
\text { MAP } 980 \mathrm{~mm} \\
\text { (fallow cycle: } \\
\text { cropping / forest) }\end{array}$} & $\begin{array}{l}\text { Chromic } \\
\text { Calcaric }\end{array}$ & $\begin{array}{l}\text { Forest }(1 \mathrm{yr} \text { after } \\
\text { reforestation) }\end{array}$ & $\begin{array}{l}52.9 \\
(\mathrm{~A}, 0-10 \mathrm{~cm})\end{array}$ & n.a. & \multirow{4}{*}{$\begin{array}{l}\text { Shang and } \\
\text { Tiessen, } 2003 \text { / } \\
\text { gas chromatogra- } \\
\text { phy }\end{array}$} \\
\hline & Regosol* & $\begin{array}{l}\text { Forest }(12 \text { yrs after } \\
\text { reforestation) }\end{array}$ & $68.9(\mathrm{~A}, 0-10 \mathrm{~cm})$ & n.a. & \\
\hline & $\begin{array}{l}\text { Calcaric } \\
\text { Humic }\end{array}$ & $\begin{array}{l}\text { Forest }(1 \mathrm{yr} \text { after } \\
\text { reforestation) }\end{array}$ & $\begin{array}{l}104.0 \\
(\mathrm{~A}, 0-10 \mathrm{~cm})\end{array}$ & n.a. & \\
\hline & $\begin{array}{l}\text { Leptosol* } \\
\text { (Regosol) }\end{array}$ & $\begin{array}{l}\text { Forest }(12 \text { yrs after } \\
\text { reforestation) }\end{array}$ & $\begin{array}{l}146.0 \\
(\mathrm{~A}, 0-10 \mathrm{~cm})\end{array}$ & n.a. & \\
\hline \multirow{5}{*}{$\begin{array}{l}\text { Guangxi Zhuang } \\
\text { (SW China), } \\
\text { MAT 15.0- } \\
18.7^{\circ} \mathrm{C} \text {, MAP } \\
1,530-1,820 \mathrm{~mm}\end{array}$} & $\begin{array}{l}\text { Calcaric } \\
\text { (Rendzic) }\end{array}$ & Arable land & $\begin{array}{l}20.86 \\
(\mathrm{~N}=3, \mathrm{~A}, 0-15 \mathrm{~cm})\end{array}$ & $\begin{array}{l}43.5 \\
(\mathrm{~N}=3,0-15 \mathrm{~cm})\end{array}$ & \multirow{5}{*}{$\begin{array}{l}\text { Yang et al., } 2016 \\
\text { / rapid } \\
\text { - dichromate } \\
\text { oxidation }\end{array}$} \\
\hline & Leptosol* & $\begin{array}{l}\text { Secondary grassland } \\
\text { after arable land } \\
(10 \text { yrs.) }\end{array}$ & $\begin{array}{l}19.91 \\
(\mathrm{~N}=6, \mathrm{~A}, 0-15 \mathrm{~cm})\end{array}$ & $\begin{array}{l}42.0 \\
(\mathrm{~N}=6,0-15 \mathrm{~cm})\end{array}$ & \\
\hline & & $\begin{array}{l}\text { Secondary shrubland } \\
\text { after arable land ( } 30 \\
\text { yrs.) }\end{array}$ & $\begin{array}{l}42.97 \\
(\mathrm{~N}=6 \mathrm{~A}, 0-15 \mathrm{~cm})\end{array}$ & $\begin{array}{l}72.5 \\
(\mathrm{~N}=6,0-15 \mathrm{~cm})\end{array}$ & \\
\hline & & $\begin{array}{l}\text { Secondary forest after } \\
\text { arable land ( } 60 \text { yrs. })\end{array}$ & $\begin{array}{l}64.59 \\
(\mathrm{~N}=6 \mathrm{~A}, 0-15 \mathrm{~cm})\end{array}$ & $\begin{array}{l}95.4 \\
(\mathrm{~N}=6,0-15 \mathrm{~cm})\end{array}$ & \\
\hline & & $\begin{array}{l}\text { Primary Forest } \\
\text { (subtropical humid } \\
\text { forest) }\end{array}$ & $\begin{array}{l}57.88 \\
(\mathrm{~N}=6 \mathrm{~A}, 0-15 \mathrm{~cm})\end{array}$ & $\begin{array}{l}89.8 \\
(\mathrm{~N}=6,0-15 \mathrm{~cm})\end{array}$ & \\
\hline \multirow{3}{*}{$\begin{array}{l}\text { Castilla y Leon } \\
\text { (NW Spain) } \\
\text { MAT } 12,3^{\circ} \mathrm{C} \text {, } \\
\text { MAP } 400 \mathrm{~mm}\end{array}$} & Calcaric Regosols* & $\begin{array}{l}\text { Arable land (since 19th } \\
\text { century) }\end{array}$ & $\begin{array}{l}15.6-27.8 \\
(\mathrm{~N}=12, \mathrm{~A}, 0-10 \mathrm{~cm})\end{array}$ & n.a. & \multirow{3}{*}{$\begin{array}{l}\text { Llorente et al., } \\
2010 \text { / gas } \\
\text { chromatography }\end{array}$} \\
\hline & & $\begin{array}{l}\text { Secondary forest } \\
\text { (Pinus sp., since 1950s, } \\
\text { followed arable land) }\end{array}$ & $\begin{array}{l}34.7-54.5 \\
(\mathrm{~N}=12, \mathrm{~A}, 0-10 \mathrm{~cm})\end{array}$ & n.a. & \\
\hline & & $\begin{array}{l}\text { Natural forest } \\
\text { (Quercus sp.) }\end{array}$ & $\begin{array}{l}54.2-65.1 \\
(\mathrm{~N}=12, \mathrm{~A}, 0-10 \mathrm{~cm})\end{array}$ & n.a. & \\
\hline \multirow{2}{*}{$\begin{array}{l}\text { Sevilleta } \\
\text { (New Mexico, } \\
\text { USA), } \\
\text { MAP } 256 \mathrm{~mm}\end{array}$} & Calcisols & $\begin{array}{l}\text { Grassland } \\
\text { (Bouteoula eripoda) }\end{array}$ & $\begin{array}{l}4.0 \\
(\mathrm{~N}=15,0-5 \mathrm{~cm})\end{array}$ & $\begin{array}{l}2.8 \\
(\mathrm{~N}=15,0-5 \mathrm{~cm})\end{array}$ & \multirow{2}{*}{$\begin{array}{l}\text { Cunliffe et al. } \\
2016 \text { / gas } \\
\text { chromatography }\end{array}$} \\
\hline & & $\begin{array}{l}\text { Shrubs } \\
\text { (Larrea tridentata) }\end{array}$ & $\begin{array}{l}4.5 \\
(\mathrm{~N}=15,0-5 \mathrm{~cm})\end{array}$ & $\begin{array}{l}3.3 \\
(\mathrm{~N}=15,0-5 \mathrm{~cm})\end{array}$ & \\
\hline
\end{tabular}

* the nearest equivalent in WRB 2015 is given;

** n.a. - not analysed. 
an effect on the form of accumulated organic matter: thicker organic horizons develop in forest soils, especially in coniferous forest (Seeber and Seeber 2005, Łabaz et al. 2014). Simultaneously a higher contribution of the free fraction of organic matter ${ }^{1}$ occurs in humus horizons of forest soils than in nonforest soils, as determined in rendzinas as well as in other soils (Kuźnicki and Skłodowski 1968, 1976, John et al. 2005, Llorente et al. 2010, Debasish-Saha et al. 2014, Wasak and Drewnik 2015).

OC sequestration in the soil directly depends on the species composition of the vegetation, because the chemical composition and structure of the plant substrate determines its susceptibility to transformations. For example, Gałka et al. (2014) found that in non-calcareous forest soils occurring under coniferous tree stands (spruce), OC sequestration is considerably higher than under deciduous tree stands (beech). This can result from lower susceptibility to decomposition of needles of coniferous trees usually showing higher $\mathrm{C} / \mathrm{N}$ ratio, lower concentration of alkaline cations, and higher content of lignines, waxes, and polyphenols in comparison to leaves of deciduous trees (Dziadowiec 1990, Albers et al. 2004, Sariyildiz et al. 2005, Hobbie et al. 2006). The consequence of the direct and indirect effect of vegetation is also the accumulation of organic matter in various forms. Under the coniferous forest stands, organic matter is particularly accumulated in the organic horizons, and under deciduous forest stands - in humus horizons of soils (Vesterdal et al. 2013). Laganiére et al. (2011) found that humus horizons of non-calcareous soils in coniferous forests contain a higher amount of free fraction of organic matter than soils under deciduous tree stands. A similar dependency was observed by Wasak (2017) in calcareous soils in the Tatra Mountains. For contrast, Llorente et al. (2010) evidenced lack of significant differences between the OC stock and contribution of particular fractions of organic matter in rendzinas under beech and pine (NW Spain). The species composition also largely determines the development of particular humus forms (Wasak 2013, Łabaz et al. 2014).

\footnotetext{
${ }^{1}$ This paper applies terms referring to physical fractioning of organic matter in the soil in accordance with the terminology applied in the paper by Leifeld and Kögel-Knabner (2005). Organic matter in the soil can occur as (1) particulate (non-humified) organic matter (1a) in the free form (free fraction) - occurring outside strong soil aggregates, and (1b) in the occluded form, occurring within strong soil aggregates (macro- or microaggregates), as well as (2) humified organic matter, bound within strong soil aggregates.
}

Therefore, a change of land use results in a change of OC stock in rendzinas, and it is important to consider the time factor in the evaluation of the phenomenon. In the conditions of subtropical climate, the changes can be very rapid. According to Shang and Tiessen (2003), the OC stock in calcareous soils on former arable land (Yucatan, Mexico) is higher by a relative $\sim 30 \% 12$ years after forestation in comparison to soils forested 1 year ago (Table 1), and the increase was the highest in the fractions of particulate soil organic matter (free and occluded in soil macroaggregates). In the moderately cool montane belt in the Tatra Mountains Wasak and Drewnik (2015) found that 50 years after the introduction of larch forest and dwarf pine in place of pastures, rendzinas show statistically significant differences in OC stock in the soil: the highest OC stock occurs in a light larch forest, somewhat lower - on a non-forested meadow, and the lowest - under dwarf pine shrubs, whereas the contribution of particulate fractions of organic matter (free and occluded in soil macroaggregates) in soil under dwarf pine and under larch is higher than in the meadow soils.

The species composition of vegetation also indirectly affects $\mathrm{OC}$ sequestration through the influence on soil chemical properties. It should be mentioned that in coniferous tree stands, intensified leaching of alkaline cations occurs as a result of bedrock weathering (Bergkvist and Folkeson 1995, Rothe et al. 2002, Drewnik et al. 2016b), whereas e.g. in beech forests, Ca collected from deeper soil horizons, of rendzinas or mostly non-calcareous brown soils developed on carbonate bedrock, are introduced to the geochemical cycle (Berger et al. 2004, 2006, 2009). Coniferous trees usually cause a decrease in soil $\mathrm{pH}$ and a decrease in base saturation in the topsoil, including rendzinas (Augusto et al. 1998, D'Amico et al. 2008, Hagen-Torn et al. 2004, Rozpędowska and Skiba 2006, Gruba and Mulder 2015, Wasak 2017). The effect of vegetation is also manifested in the fact that the forest species composition determines the topoclimatic conditions by influencing the soil temperature and moisture (Nihlgård 1970, Hobbie et al. 2006). The aforementioned phenomena can together affect the activity of soil organisms.

A discussion on the contribution of vegetation and parent material in the determination of properties of humus also has been conducted. The opinion on the critical role of vegetation was maintained for decades (among others Ovington 1953, 1954). In recent years, however, the role of soil parent material in the development of properties of organic matter has been increasingly emphasised, and insufficient knowledge on the subject has been pointed out (Ponge et al. 2011). 
If the rate of transformation of organic matter and the amount, and quality of organic substrate depend on the habitat, then parent material should have a considerable effect on processes determining the sequestration and stock of OC. Parent material is the source of cations released to the soil during weathering (Bergkvist and Folkeson 1995, Augusto et al. 2000, Norton and von Blanckenburg 2010). It determines soil $\mathrm{pH}$, and directly affects the chemical composition of plant litterfall (Ponge et al. 1999, Berger et al. 2009, Wasak 2017). This way, it can determine the biological activity of the soil (Drewnik 2006, Błońska 2015). Moreover, the content and type of clay minerals and polyvalent cations $\left(\mathrm{Fe}^{2+}, \mathrm{Al}^{3+}, \mathrm{Ca}^{2+}\right.$, $\mathrm{Mg}^{2+}, \mathrm{Mn}^{2+}, \mathrm{Zn}^{2+}, \mathrm{Cu}^{2+}$, etc.) specific to given parent material contribute to the immobilisation of humic substances in the soil (Oades 1984, Andreux 1996, Lützow et al. 2006, Egli et al. 2008, Grüneberg et al. 2014, Yang et al. 2016).

Considering the above determinations, the presence of calcium carbonate in the soil can be expected to considerably affect $\mathrm{OC}$ sequestration both directly and indirectly.

\section{ACTIVITY OF SOIL FAUNA AND MICROBIOLOGICAL ACTIVITY OF RENDZINAS}

According to many studies, rendzinas are characterised by considerably higher activity of soil fauna than the remaining soils under comparable conditions. Based on macroscopic observations and micromorphological research, it was evidenced in the conditions of humid climate: in the Alps (Kubiena 1953, Zech et al. 1986, Sartori et al. 2005), Pyrenees (Ponge et al. 2011, Zaiets and Poch 2016), and Ardennes (Ponge 1999), as well as in the territory of Poland (Kowaliński and Licznar 1986, Miechówka 1989, 2002, Ciarkowska and Miechówka 2005, Ciarkowska and Niemyska-Łukaszuk 2002, Miechówka and Ciarkowska 1998, 2002, Niemyska-Łukaszuk 1977b, NiemyskaŁukaszuk et al. 2002, Wasak, 2013). In soils of the Mediterranean (Zaiets and Poch 2016) and subtropical climates (Loranger et al. 2003) the presence of calcium carbonate was also determined to favour raised activity of soil fauna. The course of the phenomenon is the reaction of the soil solution favouring the fauna, and presence of exchangeable $\mathrm{Ca}$ (Reich et al. 2005). It should be emphasised that the high activity of soil fauna (particularly earthworms) results in the development of a strong aggregate structure in the soil (McLean and Parkinson 1997a, 1997b, Zanella et al. 2018a, 2018b).
Results of the research on the microbiological activity of rendzinas are not unambiguous. Calcareous soils are considered as soils characterised by substantial activity of soil microorganisms (e.g. Kuźnicki and Skłodowski 1976, Kowaliński and Licznar 1986). It should be emphasised, however, that this general opinion is not based on direct measurements of biological activity of the soil, but on microscopic observations that showed the results of high activity of soil mezo- (and macro-) fauna (Kowaliński and Licznar 1986, Zagórski 1999, Some studies showed, however, that the activity of soil fauna does not always favour the microbiological activity of the soil. Ciarkowska and Miechówka (2005) evidenced that the biological activity in carbonate and sulphate rendzinas from Poland and from Dolomites (the Alps) is inversely correlated with the activity of dehydrogenases in such soils. The authors explain it with soil mezofauna feeding on microorganisms. In his laboratory experiment, Martin (1991) evidenced that in soil containing endogenic earthworms after a year of conducting the experiment the rate of mineralisation of organic matter was almost 4 times lower in comparison to the soil lacking the animals. This can be explained by limiting the accessibility of organic matter for microorganisms in the process of occlusion or impoverishment of organic matter in the easiest absorbable components after passing through the digestive tract of soil fauna (McLean and Parkinson 1997a, 1997b, Rawlins et al. 2007).

A certain argument sustaining the opinion on high microbiological activity of rendzinas are study results evidencing that relatively high content of exchangeable base cations in the soils developed under temperate climate favours the microbiological activity (Dziadowiec 1990, Błońska 2015). It has to be considered, however, that in this climatic zone, the majority of soils are characterised by strong leaching, and that the aforementioned research was conducted in acidic soils. Rendzinas show high contents of base exchangeable cations, but other processes also occur, as described below.

An important voice in the discussion on microbiological activity in carbonate soils are experimental study results. Results of a laboratory experiment conducted by Muneer and Oades (1989a) showed that addition of glucose and substances being a source of $\mathrm{Ca}$ to the soil decreased the release of carbon dioxide, and therefore decreased soil biological activity, although addition of the same glucose had a stimulating effect on the microbiological activity of the soil.

Direct measurements of microbiological activity in rendzinas have been scarce in Poland. Such research, however, has been conducted at a quite extensive scale 
in soils rich in calcium carbonate in dry and Mediterranean climates, where the considerably lower microbiological activity was reported as compared to the neighbouring non-calcareous soils. Garcia et al. (1994) determined low activity of dehydrogenases and lower respiration in rendzinas in south-west Spain than in the other soils of the region. Similarly, Llorente and Belén Turrión (2010) found low value of respiration and biomass of soil microorganisms in rendzinas in north Spain. Quantitative values of the microbiological activity were negatively correlated with the content of carbonates in the soil. El-Saied et al. (2016) determined low activity of dehydrogenases and phosphatase in carbonate soils in Egypt. The primary cause of the phenomenon is considered to be a decrease in the availability of certain nutrients important for soil microorganisms (particularly N, P, $\mathrm{K}$ and some microelements) caused by high soil saturation with $\mathrm{Ca}$ and $\mathrm{Mg}$ (Carreira et al. 1997, Tejada et al. 2006, El-Saied et al. 2016).

In Poland, Drewnik (1998) observed that in the upper mountain forest zone of the Tatra Mountains, the loss of cellulose mass in the humus horizon in rendzina was smaller than in podzol. Wasak (2014, 2017) found that the microbiological activity of rendzinas under beech and spruce forests in the Tatra Mountains, measured both as the rate of cellulose decomposition under field conditions and rate of soil respiration measured under laboratory conditions, is considerably lower in calcareous soils than in noncalcareous Cambisols. The research showed that the lower decomposition in rendzinas takes place both in humus horizons and in organic horizons. The biological activity in the humus and organic horizons of the soils under investigation showed a strong negative correlation with the content of exchangeable $\mathrm{Mg}$, and in the organic horizon - a positive correlation with the content of K. The correlation between the soil biological activity and content of $\mathrm{K}$ exclusively of an organic horizons is probably the effect of an antagonism in the collecting cations by roots of plants in rendzinas (Robins and Mayland 1993). High content of $\mathrm{Mg}$ in the soils can inhibit uptake of $\mathrm{K}$ by tree roots, resulting in a lower concentration of $\mathrm{K}$ in plant tissues, and consequently also their lower content in the organic horizons. A low microbiological activity of the soil, particularly in humus horizons of soils containing carbonates, can also be the result of a low content of the dissolved fraction of organic carbon (DOC) in the soil saturated with $\mathrm{Ca}$. As revealed by Andersson et al. (2000), the presence of a considerable amount of exchangeable Ca promotes immobilisation of DOC as well as the other humus compounds, and this carbon fraction is among the most important sources of carbon for microorganisms (Kalbitz et al. 2000). An indirect proof for relatively low microbiological activity in rendzinas is the higher contribution of carbon of the free fraction of organic matter (not bound to soil aggregates) in rendzinas as compared to the other soils - e.g. brown soils, as evidenced by Miechówka (2000) in the soils of pastures and Wasak (2017) in forest soils in the Tatra Mountains.

The presented study results show that the microbiological activity of rendzinas can be limited by deficiency of certain components caused by high content of soluble $\mathrm{Ca}$ and $\mathrm{Mg}$ resulting from the presence of calcium carbonate in the parent material (e.g. rendzinas), or the presence of secondary carbonates, as in the soils of dry climate. This can be one of the causes of higher OC sequestration in such soils.

\section{HUMIFICATION PROCESSES AND STABILISATION OF ORGANIC MATTER}

The accumulation of humified organic matter in the form of humic bonds or polysaccharides in the presence of polyvalent $\mathrm{Ca}^{2+}$ and $\mathrm{Mg}^{2+}$ ions and clay minerals has been identified a long time ago (Dobrzański and Turski 1972, Oades 1984, Ladd et al. 1985, Muneer and Oades 1989a, 1989c, Andreux 1996, Zech and Guggenberger 1996, Baldock and Skjemstad 2000, Clough and Skjemstad 2000, Lützow et al. 2006). An important input in the understanding of the causes of the phenomenon are the experiments of Juste and Delas (1970) and Juste et al. (1975) (cited after: Baldock and Skjemstad 2000) who showed lower microbiological activity of the soil in the case of saturation of humic compounds with $\mathrm{Ca}^{2+}$ ions, and of Muneer and Oades (1989a), who showed that addition of the glucose and Ca to the soil have decreased the biological activity of the soil. Yang et al. (2016) showed that the contribution of exchangeable $\mathrm{Ca}$ and $\mathrm{Mg}$ is the most important factor determining OC stock in the soils of the south China, followed by the content of clay minerals. Ladd et al. (1985) evidenced that carbonate soils in south Australia containing more than $40 \%$ clay minerals maintained constant stock of OC $\left({ }^{14} \mathrm{C}\right)$ added to the soil before 8 years, whereas in soils containing approximately $5 \%$ clay minerals, a considerable decrease of the content of OC was noted, amounting to approximately $40 \%$ of the original content. Denef and Six (2004) discuss the type of clay minerals in $\mathrm{OC}$ sequestration: illite causes stronger bonding of OC than vermiculite.

Valuable information on the binding of humic substances in rendzinas in Poland was provided by 
numerous research based on the fractioning of humic substances (Dobrzański and Turski 1972, Kowaliński et al. 1985, Kuźnicki and Skłodowski 1968, 1973, 1976, Licznar et al. 1993, Wasak and Drewnik 2012). Although the results are difficult to compare due to the different methods used for fractioning, they show that rendzinas are characterised by a substantial contribution of the fraction related to the mineral part of the soil (and therefore humins) and humic acids bound with $\mathrm{Ca}^{2+}$ ions. High carbon content in such fractions is particularly characteristic of rendzinas containing a high contribution of active carbonates or exchangeable Ca (Kuźnicki and Skłodowski 1968, 1973, 1976, Dobrzański and Turski 1972, Kowaliński et al. 1985, Licznar et al. 1993, Wasak and Drewnik 2012). The research on the humus composition provided information on the course of the humification processes in rendzinas. Kuźnicki and Skłodowski $(1968,1973,1976)$ as well as Kowaliński et al. (1985) have emphasised that rendzinas are characterised by a higher fulvic acids to humic acids ratio than other soils, which according to the authors suggests the inhibition of polymerisation of humic substances in the soils at a certain stage of their transformations. Based on differences in optical density of humic acids, Kuźnicki and Skłodowski (1976) found that rendzinas rich in active carbonates are characterised by a low degree of condensation of aromatic structures in humic acids in comparison to rendzinas containing a small amount of active carbonates. Authors have interpreted the phenomenon as a result of calcium humates development and blocking of further transformations of humic acids. A similar phenomenon was also described, based on the analysis of C-NMR spectra of the Alpine rendzinas by Zech et al. (1986), and by Wasak (2017) based on C-NMR spectra of humic acids extracted from dolomitic rendzinas in the Tatra Mountains. They found that the amount of aliphatic substances increase with soil depth despite of decreasing the amount of polysaccharides, while the amount of aromatic bonds do not change.

The physical fractioning of the soil organic matter (Shang and Tiessen 2003, Llorente et al. 2010, Wasak 2017) indicates that rendzinas, compared to the other soils, show relatively high accumulation of particulate organic matter not only in the free form, but also occluded in large soil aggregates. The cause of the phenomenon are particular properties of the aggregate structure of the soils. Wasak (2017) evidenced in the Tatra Mountains that in the humus horizons of the calcareous soils, compared to noncalcareous soils, a higher total contribution of carbon of non-humified organic matter occurs occluded in soil aggregates (particularly in macroaggregates).
This was confirmed qualitatively by micromorphological research that showed the occurrence of strongly fragmented, but undecomposed plant tissues containing phlobaphenes (phlobaphene - brown amorphous colouring matters which are present in the walls of the bark-cells of trees and shrubs) within the aggregates. For comparison - in the brown soils, such fragments have not been observed, but the occurrence of a considerably higher amount of amorphous organic matter was found (Wasak 2017). The presence of tissues containing phlobaphenes in rendzinas was also observed by Kowaliński and Licznar (1984), and Kowaliński et al. (1985) in humus horizons of the rendzinas developed from weathered Jurassic marls in SW Poland, and by Zaiets and Poch (2016) in the rendzinas of the Pyrenees, although they did not analyse the phenomenon in quantitative terms. Accumulation of the weakly decomposed organic matter was therefore observed in rendzinas due to the existence of strong soil aggregates, as described by Oades (1984) and Lützow et al. (2006).

As mentioned above, rendzinas are characterised by the occurrence of strong aggregate structure (Duchaufour 1982, Muneer and Oades 1989a, $1989 b, 1989 c$, Bryan 2000). Its durability is caused by the activity of earthworms, contribution of $\mathrm{Ca}$ and $\mathrm{Mg}$, and the presence of clay minerals in the weathered carbonate rocks (Egli et al. 2008, Yang et al. 2016). Such structure can limit the access of microorganisms to organic matter, as theoretically described Oades (1984) and Lützow et al. (2006) pointing to a number of possible mechanisms inhibiting the microbiological decomposition of organic fragments occluded within aggregates (lack of oxygen in the microscale, physical inaccessibility of substrate for microorganisms, resistance of organic matter bound to the mineral part). The aforementioned laboratory experiment of Muneer and Oades (1989a, 1989c), and their field experiment (1989b) pointed to the key role of $\mathrm{Ca}^{2+}$ ions in an increase in the number of strong soil micro- and macroaggregates and secondary slowing down of transformation of dead organic matter after the development of the aggregates. Therefore it was evidenced that the presence of $\mathrm{Ca}^{2+}$ ions increases the strength of soil aggregates, which then results in slowing down of the decomposition of organic remains in the soil.

The literature also describes another mechanism of accumulation of non-humified organic matter in the soil involving incrustation of organic matter by crystals of precipitating calcium carbonate (which inhibits microbiological decomposition). This phenomenon was described by Duchaufour (1976 cited after Baldock and Skjemstad 2000) and Oyonarte et al. (1994) in soils developed under Mediterranean 
climate. No secondary precipitation of calcium carbonate crystals was observed in the rendzinas of the Tatra Mountains (Wasak, 2017). This probably results from different climate conditions (considerable prevalence of precipitation over evaporation) in the Tatra Mountains, and consequently leaching of calcium carbonate from the soil (Miechówka 1990), and partially also the specificity of the bedrock constituting dolomite relatively resistant to weathering. Zagórski (2003) observed the phenomenon of filling soil pores by secondary precipitating carbonates in the Niecka Nidziańska, in rendzinas developed from marls very susceptible to chemical weathering. A similar phenomenon was observed by Šamonil (2007) in the rendzinas of the Bohemian Karst. In both cases, precipitates of calcium carbonate were observed in the subsoil horizons (B, BC, or C), and not in the humus horizon in which $\mathrm{OC}$ concentration is the highest. Such an occlusion of weakly transformed organic matter in rendzinas probably has limited importance in humid climate, but can be very important in carbonate soils of dry and semi-dry climates (Baldock and Skjemstad 2000).

\section{CLASSIFICATION OF HUMUS FORMS}

Kubiena (1953), conducting research in the Alps, was the first to describe the exceptional character of humus forms present in the rendzinas (both organic and humus horizons). They were characterised by considerable thickness and high activity of soil fauna. Such humus forms, described as amphi and tangel, were described in later studies from the Alps (Zech et al. 1986, Sartori et al. 2005, Ponge et al. 2011), Pyrenees, the Mediterranean area (Ponge et al. 2011, Zaiets and Poch 2016, Andreetta et al. 2017, Vacca et al. 2017), Ardennes (Ponge 1999), and in Poland from the Tatra and Pieniny Mountains (Miechówka 1989, 2000, 2002, Drewnik 1998, Ciarkowska and Miechówka 2005, Wasak 2013). Particular humus forms, namely amphi and tangel were suggested to be included in the WRB classification (Jabiol et al. 2013) and in the planned unified classification of humus forms (Zanella et al. 2018a, 2018b).

The amphi humus form is characterised by high activity of soil fauna in the humus and organic horizons, and simultaneously by low microbiological activity, and therefore accumulation of organic matter in the humus and organic horizons, a soil reaction $\mathrm{pH}$ $\geq 5$ in humus horizons, and considerable thickness of humus horizons (Jabiol et al. 2013, Zanella et al. 2018b). Typologically similar tangel humus form is characterised by weakly developed humus horizon or its lack due to the shallow presence of the solid rock (Zanella et al. 2018b, Jabiol et al. 2013).

According to the authors of the aforementioned studies (Jabiol et al. 2013, Zanella et al. 2018b), the development of these humus forms is a result of several factors, among others saturation with $\mathrm{Ca}^{2+}$ ions (which favours the activity of soil fauna) with simultaneous periodical slowing down of biological activity in soil (Zanella et al. 2018b, Ponge et al. 2011).

\section{SUMMARY}

In terms of accumulation and transformations of organic matter, carbonate soils are exceptional soils. This is due to their strong aggregate structure and considerable concentration of $\mathrm{Ca}$ and $\mathrm{Mg}$. They are characterised by high potential of $\mathrm{OC}$ sequestration resulting from the stabilisation of organic compounds on a various functional level. Rendzinas show the following processes favouring OC sequestration: (1) strong organic-mineral bonds develop between organic compounds and $\mathrm{Ca}^{2+}$ and $\mathrm{Mg}^{2+}$ ions and clay minerals, (2) occlusion of weakly decomposed organic matter occurs in soil aggregates, (3) low rate of the microbiological activity (accumulation of free organic matter outside aggregates). All these processes overlap generating a number of feedback effects.

Similarly as in the case of other soils, the stock and dynamics of accumulation of OC as well as accumulation of organic matter in different forms in rendzinas depend on many factors, such as land use and climatic conditions. An important factor shaping sequestration of OC in carbonate soils is the type of parent material, determining the content of $\mathrm{Ca}$ and $\mathrm{Mg}$ and the amount and type of clay minerals. All the processes described above lead to the development of particular morphological properties of rendzinas with a thick humus horizon, and in certain conditions - also specific types of humus forms.

Carbonate soils constitute a very interesting subject of research on the processes of $\mathrm{OC}$ sequestration in the soil. Further studies on the phenomenon should employ a broad spectrum of methods of biological, biochemical, microbiological, pedological, mineralogical, and micromorphological research. It requires a comprehensive investigation of the complex mechanisms of transformations of organic matter functioning in the soils.

\section{ACKNOWLEDGEMENTS}

The authors are grateful to the anonymous reviewer for their insightful and constructive comments that significantly increased the scientific quality of the paper. 


\section{REFERENCES}

Ahmed Y.A.R., Pichler V., Homolák M., Gömöryová, E., Nagy D., Pichlerová, M., Gregor J., 2012. High organic carbon stock in a karstic soil of the Middle-European Forest Province persists after centuries-long agroforestry management. European Journal of Forest Research 131: 1669-1680.

Albers D., Migge S., Schaefer M., Scheu S., 2004. Decomposition of beech leaves (Fagus sylvatica) and spruce needles (Picea abies) in pure and mixed stands of beech and spruce. Soil Biology and Biochemistry 26: 155-164.

Andersson S., Nilsson I., Saetre P., 2000. Leaching of dissolved organic carbon (DOC) and dissolved organic nitrogen (DON) in mor humus as affected by temperature and $\mathrm{pH}$. Soil Biology and Biochemistry 32: 1-10.

Andreetta A., Cecchini G., Carnicelli S., 2017. Forest humus forms in Italy: A research approach. Applied Soil Ecology. https://doi.org/10.1016/j.apsoil.2017.09.029

Andreux F., 1996. Humus in world soils. [In:] Humic Substances in Terrestrial Ecosystems (Piccolo A., Editor). Elsevier, Amsterdam: 45-100.

Augusto L., Bonnaud P., Ranger J., 1998. Impact of tree species on forest soil acidification. Forest Ecology and Management 105: 67-78.

Augusto L., Turpault M.P., Ranger J., 2000. Impact of forest tree species on feldspar weathering rates. Geoderma 96: 215-237.

Baldock J.A., Skjemstad J.O., 2000. Role of the soil matrix and minerals in protecting natural organic materials against biological attack. Organic Geochemistry 31: 697-710.

Baritz R., Seufert G., Montanarella L., VanRanst E., 2010. Carbon concentrations and stocks in forest soils of Europe. Forest Ecology and Management 260: 262-277.

Berger T.W., Inselsbacher E., Mutsch F., Pfeffer M., 2009. Nutrient cycling and soil leaching in eighteen pure and mixed stands of beech (Fagus sylvatica) and spruce (Picea abies). Forest Ecology and Management 258: 2578-2592.

Berger T.W., Köllensperger G., Wimmer R., 2004. Plant-soil feedback in spruce (Picea abies) and mixed spruce-beech (Fagus sylvatica) stands as indicated by dendrochemistry. Plant and Soil 264: 69-83.

Berger T.W., Swoboda S., Prohaska T., Glatzel G., 2006. The role of calcium uptake from deep soils for spruce (Picea abies) and beech (Fagus sylvatica). Forest Ecology and Management 229: 234-246.

Bergkvist B., Folkeson L., 1995. The influence of tree species on acid deposition, proton budgets and element fluxes in south Swedish forest ecosystems. Ecological Bulletins 44: 90-99.

Błońska E., 2015. Effects of stand species composition on the enzyme activity and organic matter stabilization in forest soil. Zeszyty Naukowe Uniwersytetu Rolniczego im. Hugona Ko1łątaja w Krakowie 404: 1-85.

Bojko O., Kabała C., 2016. Transformation of physicochemical soil properties along a mountain slope due to land management and climate changes - a case study from the Karkonosze Mountains, SW Poland. Catena 140: 43-54.

Bryan R.B., 2000. Soil erodibility and processes of water erosion on hillslope. Geomorphology 32(3-4): 385-415.

Budge K., Leifeld J., Hiltbrunner E., Fuhrer J., 2010. Litter quality and $\mathrm{pH}$ are strong drivers of carbon turnover and distribution in alpine grassland soils. Biogeosciences Discussions 7: 62076242.

Carreira J.A., Laitha K., Njell F.X., 1997. Phosphorus transformations along a soil/vegetation series of fire-prone, dolomitic, semi-arid shrublands of southern Spain. Biogeochemistry 39: 87-129.

Ciarkowska K., Miechówka A., 2005. Biological activity of mountain humic rendzinas formed on calcarous and sulphate rocks. Part I. Micromorphological indexes of soil fauna activity and dehydrogenase activity. Problemy Zagospodarowania Ziem Górskich 52: 57-64 (In Polish).

Ciarkowska K., Niemyska-Łukaszuk J., 2002. Microstructure of humus horizons of gypsic soils from the Niecka Nidziańska area (South Poland). Geoderma 106: 319-329.

Clough A., Skjemstad J.O., 2000. Physical and chemical protection of soil organic carbon in three agricultural soils with different contents of calcium carbonate. Australian Journal of Soil Research 38(5): 1005-1016.

Cunliffe A.M., Puttock A.K., Turnbull L., Wainwright J., Brazier R.E., 2016. Dryland, calcareous soils store (and lose) significant quantities of near-surface organic carbon, Journal of Geophysical Research. Earth Surface 121: 684-702.

D’Amico M., Julitta F., Previtali F., Cantelli D., 2008. Podzolization over ophiolitic materials in the western Alps (Natural Park of Mont Avic, Aosta Valley, Italy). Geoderma 146: 129-137.

Davidson E.A., Janssens I.A., 2006. Temperature sensitivity of soil carbon decomposition and feedbacks to climate change. Nature 440: 165-173.

Debasish-Saha S.S., Kukal S.S., Bawa S.S., 2014. Soil organic carbon stock and fractions in relation to land use and soil depth in the degraded Shiwaliks hills of Lower Himalayas. Land Degradation and Development 25: 407-416.

Denef K., Six J., 2004. Clay mineralogy determines the importance of biological versus abiotic processes for macroaggregate formation and stabilization. European Journal of Soil Science 56: 469-479.

Dobrzański B., Turski R., 1972. Rendzinas of the Lubelska Upland developed of carbonate rocks of cretaceous period (in Polish). Roczniki Nauk Rolniczych, seria D, Monografie 148: $1-80$.

Drewnik M., 1998. Geoecological modalities of humus horizons development in the mountain soils (Polish Carpathians). PhD thesis. IGiGP Kraków. 107 pp. (manuscript, in Polish).

Drewnik M., 2006. The effect of environmental conditions on the decomposition rate of cellulose in mountain soils. Geoderma 132: 116-130.

Drewnik M., Musielok Ł., Stolarczyk M., Mitka J., Gus M., 2016a. Effects of exposure and vegetation type on organic matter stock in the soils of subalpine meadows in the Eastern Carpathians. Catena 147: 167-176.

Drewnik M., Wasak K., Żelazny M., Jelonkiewicz Ł., 2016 b. Dissolution of carbonate rock in soils under beech and spruce forests in the laboratory conditions. Sylwan 160(9): 751-758. (in Polish).

Duchaufour P., 1982. Calcimagnesian soils. [In:] Pedology. Springer, Dordrecht.

Duchaufour P., 1976. Dynamics of organic matter in soils of temperate regions: its action on pedogenesis. Geoderma 15: 31-40.

Dziadowiec H., 1990. Decomposition of litter, in chosen forest ecosystems (mineralization, releasing nutrients, humification). Rozprawy Uniwersytetu Mikołaja Kopernika, Torun: 137 pp. (in Polish).

Egli M., Merkli C., Sartorti G., Mirabella A., Plötze M., 2008. Weathering, mineralogical evolution and soil organic matter along a Holocene toposequence developed on carbonate-rich materials. Geomorphology 97: 675-696. 
El-Saied H., El-Hady O.A., Basta A.H., El-Dewiny C.Y., AboSedera C., 2016. Bio-chemical properties of sandy calcareous soil treated with rice straw-based hydrogels. Journal of the Saudi Society of Agricultural Sciences 15: 188-194.

FAO 1996. Digital soil map of the world and derived soil properties. Vers. 3.5., Nov, 1995. FAO, Rome.

Gałka B., Łabaz B., Bogacz A., Bojko O., Kabała C., 2014. Conversion of Norway spruce forests will reduce organic carbon pools in the mountain soils of SW Poland. Geoderma 213: $287-295$.

García C., Hernández T., Costa F., 1994. Microbial activity in soils under Mediterranean environmental conditions. Soil Biology and Biochemistry 26: 1185-1191.

Gonet S.S., Dębska B., Dziamski A., Banach-Szott M., Zaujec A., Szombathová N., 2009. Properties of organic matter in Haplic Luvisol under arable, meadow and forest management. Polish Journal of Soil Science 42(2): 139-148.

Gruba P., Mulder J., 2015. Tree species affect cation exchange capacity (CEC) and cation binding properties of organic matter in acid forest soils. Science of the Total Environment 511: 655-662.

Grüneberg E., Ziche D., Wellbrock N., 2014. Organic carbon stocks and sequestration rates of forest soils in Germany. Global Change Biology 20: 2644-2662.

Guo L.B., Gifford R.M., 2002. Soil carbon stocks and land use change: a meta-analysis. Global Change Biology 8: 345-360.

Hagen-Thorn A., Callesen I., Armolaitis K., Nihlgard B., 2004. The impact of six European tree species on the chemistry of mineral topsoil in forest plantations on former agricultural land. Forest Ecology and Management 195: 373-384.

Hobbie S.E., Reich P.B., Oleksyn J., Ogdahl M., Zytkowiak R., Hale C., Karolewski P., 2006. Tree species effects on decomposition and forest floor dynamics in a common garden. Ecology 87: 2288-2297.

Jabiol B., Zanella A., Ponge J. F., Sartori G., Englisch M., van Delf B., de Waal R., Le Bayon R.C., 2013. A proposal for including humus forms in the World Reference Base for Soil Resources (WRB-FAO). Geoderma 192: 286-294.

Jobbágy E.G., Jackson R.B., 2000. The vertical distribution of soil organic carbon and its relation to climate and vegetation. Ecological Applications 10(2): 423- 436.

John B., Yamashita T., Ludwig B., and Flessa H., 2005. Storage of organic carbon in aggregate and density fractions of soils under different types of land use. Geoderma 128: 63-79.

Juste C., Delas J., 1970. Comparison par une méthod respirométique, des solubilités bioliquies d'un humate de calcium et du'un humate de sodium. Comptes Rendus Hebdomadaires des Seances de l'Academie des Sciences, D270- 1127-1129 (in French).

Juste C., Delas J., Langon M., 1975. Comparison de la stabilités biologique de différents humates metalliques. Comptes Rendus Hebdomadaires des Seances de l'Academie des Sciences D281: 1685-1688 (in French).

Kalbitz K., Solinger S., Park J.-H., Michalzik B., Matzner E., 2000. Controls on the dynamics of dissolved organic matter in soils: a review. Soil Science 165: 277-304.

Kim C., 2000. Canopy cover effects on cellulose decomposition in oak and pine stands. Journal of Forest Research 5: 145-149.

Kowaliński S., Licznar S.E., 1984. Micromorphological and physico-chemical properties of rendzina soils occurring on the Nysa Kłodzka trough area. Roczniki Gleboznawcze - Soil Science Annual 35(1): 125-139 (in Polish).

Kowaliński S., Licznar S.E., 1986. Humus compounds in rendzina soils formed out of limestones of different geological formations. Roczniki Gleboznawcze - Soil Science Annual 37(2-3): 159-167 (in Polish).

Kowaliński S., Licznar S.E., Licznar M., 1985. Micromorphological and chemical characteristics of humus in rendzina soils developed from limestones of different geological formations. Roczniki Gleboznawcze - Soil Science Annual 36(3): 165-172.

Kubiena W.L., 1953. The soils of Europe. Thomas Murby and Co. London: 318 pp.

Kurz-Besson C., Coüteaux M.M., Berg B., Remacle J., Ribeiro C., Romanyŕ J., Thiéry J. M., 2006. A climate response function explaining most of the variation of the forest floor needle mass and the needle decomposition in pine forests across Europe. Plant and Soil 285: 97-114.

Kuźnicki F., Skłodowski P., 1968. Organic substance changes in some soil types in Poland. Roczniki Gleboznawcze - Soil Science Annual 19(1): 3-25 (in Polish).

Kuźnicki F., Skłodowski P., 1973. Content of various forms of humus compounds in rendzina soils as compared with other soil types. Roczniki Gleboznawcze - Soil Science Annual 24(2): 187-199 (in Polish).

Kuźnicki F., Skłodowski P., 1976. Content and characteristics of the forms of humus compounds in rendzinas developed from carbonate rocks of different geological age. Roczniki Gleboznawcze - Soil Science Annual 27(2): 127-136 (in Polish).

Ladd J.N., Amato M., Oades J.M., 1985. Decomposition of plant material in Australian soils. III. Residual organic and microbial biomass $\mathrm{C}$ and $\mathrm{N}$ from isotope labelled plant material and organic matter decomposing under field conditions. Australian Journal of Soil Research 23: 603-611.

Laganiére, J., Angers D. A., Parč D., 2010. Carbon accumulation in agricultural soils after afforestation: a meta-analysis. Global Change Biology 16: 439-453.

Laganiére J., Angers D.A., Paré D., Bargeron Y., Chen H.Y.H., 2011. Black spruce accumulate more uncomplexed organic matter than aspen soils. Soil Science Society of America Journal 75: 1125-1132.

Lal R., 2004. Soil carbon sequestration to mitigate climate change. Geoderma 123: 1-22.

Leifeld J., Zimmermann M., Fuhrer J., Conen F., 2009. Storage and turnover of carbon in grassland soils along an elevation gradient in the Swiss Alps. Global Change Biology 15: 668-679.

Leifeld J., Kögel-Knabner I., 2005. Soil organic matter as early indicators for carbon stock changes under different land-use? Geoderma 124: 143-155.

Lemtiri A., Colinet G., Alabi T., Cluzeau D., Zirbes L., Haubruge É., Francis F., 2014. Impacts of earthworms on soil components and dynamics. A review. Biotechnology, Agronomy, Society and Environment 18: 1-13.

Licznar S.E., Drozd J., Licznar M., 1993. Fractional composition of humus in rendzina soils developed in South-West region of Poland 411: 131-138 (in Polish).

Llorente M., Belén Turrión M., 2010. Microbiological parameters as indicators of soil organic carbondynamics in relation to different land use management European Journal of Forest Research 129: 73-81.

Llorente M., Glaser B., Belén Turrión M., 2010. Storage of organic carbon and black carbon in density fractions of calcareous soils under different land uses. Geoderma 159: 31-38.

Loranger G., Ponge J.F., Lavelle P., 2003. Humus forms in two secondary semievergreen tropical forest stands. European Journal of Soil Sciences 54: 17-24.

Lützow M. v., Kögel-Knabner I., Ekschmitt K., Matzner E., Guggenberger G., Marschner B., Flessa H., 2006. Stabiliza- 
tion of organic matter in temperate soils: mechanisms and their relevance under different soil conditions - a review. European Journal of Soil Science 57: 426-445.

Łabaz B., Gałka B., Bogacz A., Waroszewski J., Kabała C., 2014. Factors influencing humus forms and forest litter properties in the mid-mountains under temperate climate of southwestern Poland. Geoderma 230-231: 265-273.

Martin A., 1991. Short-term and long-term effect of the endogeic earthworm Millsonia anomala (Omodeo) (Megascolecidae, Oligochaeta) of tropical savannas on soil organic matter. Biology and Fertility of Soils 11: 234-238.

McLean M.A., Parkinson D., 1997a. Changes in structure, organic matter and microbial activity in pine forest soil following the introduction of Dendrobaena octaedra (Oligochaeta, Lumbricidae). Soil Biology and Biochemistry 29: 537-540.

McLean M.A., Parkinson D., 1997b. Soil impacts of the epigeic earthworm Dendrobaena octaedra on organic matter and microbial activity in lodgepole pine forest. Canadian Journal of Forest Research 27: 1907-1913.

Miechówka A., 1989. Geochemical characteristics of Tatra rendzinas formed on dolomites. Part I. General features of soils and some mineralogical data. Roczniki Gleboznawcze - Soil Science Annual 4(2): 83-105 (in Polish).

Miechówka A., 1990. Geochemical characteristic of rendzinas of the Tatra Mts. formed on dolomites. Part II. Chemical properties of investigated soils (in Polish). Roczniki Gleboznawcze - Soil Science Annual 41(3-4): 29-48.

Miechówka A., 2000. Characteristics of non-forested soils of the Tatra Mountains formed on calcareous rocks. Rozprawy Akademii Rolniczej im. H. Kołłątaja w Krakowie: 86 pp.

Miechówka A., 2002. Selected properties of rendzinas occurring under dwarf pine in the Tatra National Park (in Polish). Roczniki Gleboznawcze - Soil Science Annual 53: 1-8.

Miechówka A., Ciarkowska K., 1998. Micromorphological form of humus in humous and raw humous Tatra rendzinas. Zeszyty Problemowe Postępów Nauk Rolniczych 464: 161-168 (in Polish).

Miechówka A., Ciarkowska K., 2002. The activity of soil fauna in non-forested humic rendzinas in the Tatra National Park. Przemiany środowiska przyrodniczego Tatr, Kraków-Zakopane: $111-115$.

Muneer M., Oades J.M., 1989a. The role of Ca-organic interactions in soil aggregate stability 1 . Laboratory studies with ${ }^{14} \mathrm{C}$-glucose, $\mathrm{CaCO}_{3}, \mathrm{CaSO}_{4} \cdot 2 \mathrm{H}_{2} \mathrm{O}$. Australian Journal of Soil Research 27: 389-399.

Muneer M., Oades J.M., 1989b. The role of Ca-organic interactions in soil aggregate stability 2 . Field studies with ${ }^{14} \mathrm{C}$-labelled straw, $\mathrm{CaCO}_{3}, \mathrm{CaSO}_{4} \cdot 2 \mathrm{H}_{2} \mathrm{O}$. Australian Journal of Soil Research 27: 401-409.

Muneer M., Oades J.M., 1989c. The role of Ca-organic interactions in soil aggregate stability 3 . Mechanisms and models. Australian Journal of Soil Research 27: 411-423.

Niemyska-Łukaszuk J., 1977a. Characteristics of the humus of some forest soils In the Tatra Mts. Part II: Fractionary composition of the humus compounds. Roczniki Gleboznawcze - Soil Science Annual 28(1): 169-188.

Niemyska-Łukaszuk J., 1977b. Characteristics of the humus of some forest soils in the Tatra Mts. Part III: Micromorphology of the raw humus horizons. Roczniki Gleboznawcze - Soil Science Annual 28(1): 189-203.

Niemyska-Łukaszuk J., Miechówka A., Zaleski T., 2002. The soils of Pieniny National Park and their threats. Pieniny Przyroda i Człowiek 7: 79-90 (in Polish).
Nihlgård B., 1970. Precipitation, its chemical composition and effect on soil water in a beech and a spruce forest in south Sweden. Oikos 21: 208-217.

Norton K.P., Blanckenburg F.v., 2010. Silicate weathering of soil-mantled slopes in an active Alpine landscape. Geochimica et Cosmochimica Acta 74: 5243-5258.

Oades J.M., 1984. Soil organic matter and structural stability: mechanisms and implications for management. Plant and Soil 76: 319-337.

Ohno T., Grunes D., 1985. Potassium-magnesium interactions affecting nutrient uptake by wheat forage. Soil Science Society of America Journal 49: 685-690.

Ovington J.D., 1953. Studies of the development of woodland conditions under different trees. I. Soils $\mathrm{pH}$. Journal of Ecology 41(2): 13-34.

Ovington J.D., 1954. Studies of the development of woodland conditions under different trees. II. The Forest Floor. Journal of Ecology 42(1): 71-80.

Oyonarte C., Pérez-Pujalte A., Delgado G., Delgado R., Almendros G., 1994. Factors affecting soil organic matter turnover in a Mediterranean ecosystems from Sierra de Gador (Spain): An analytical approach. Communications in Soil Science and Plant Analysis 25(11-12): 1929-1945.

Ponge J.F., 1999. Horizons and humus forms in beech forests of the Belgian Ardennes. Soil Science Society of America Journal 63: 1888-1901.

Ponge J.F., Jabiol B., Gégout J.C., 2011. Geology and climate conditions affect more humus forms than forest canopies at large scale in temperate forests. Geoderma 162: 187-195.

Ponge J.F., Patzel N., Delhaye L., Devigne E., Levieux C., Beros P., Wittebroodt R., 1999. Interactions between earthworms, litter and trees in an old-growth beech forest. Biology and Fertility of Soils 29: 360-370.

Rawlins A.J., Bull I.D., Ineson P., Evershed R.P., 2007. Stabilisation of soil organic matter in invertebrate faecal pellets through leaf litter grazing. Soil Biology and Biochemistry 39: 1202-1205.

Reich P.B., Oleksyn J., Modrzynski J., Mrozinski P., Hobbie S.E., Eissenstat D.M., Chorover J., Chadwick O.A., Hale C.M., Tjoelker M.G., 2005. Linking litter calcium, earthworms and soil properties: a common garden test with 14 tree species. Ecology Letters 8: 811-818.

Robbins C.W., Mayland H.F., 1993. Calcium, magnesium, and potassium uptake by crested wheatgrass grown on calcareous soils. Communications in Soil Science and Plant Analysis 24: 915-926.

Rothe A., Huber C., Kreutzer K., Weis W., 2002. Deposition and soil leaching in stands of Norway spruce and European beech: results from the Höglwald research in comparison with other case studies. Plant and Soil 240: 33-45.

Rozpędowska E., Skiba S., 2006. Influence of the habitat incompatible spruce vegetation on soils in Carpathians. Roczniki Bieszczadzkie 14: 237-245.

Šamonil P., 2007. Uniqueness of limestone soil-forming substrate in the forest ecosystems classification. Journal of Forest Science 53: 149-161.

Sariyildiz T., Tüfekçioğlu A., Küçük M., 2005. Comparison of decomposition rates of oriental beech (Fagus orientalis Lipsky) and oriental spruce (Picea orientalis (L.) Link) litter in pure and mixed stands of both species in Artvin, Turkey. Turkish Journal of Agriculture and Forestry 29: 429-438.

Sartori G., Mancabelli A., Wolf U., Corradini F., 2005. Atlante dei suoli del Parco Naturale Adamello-Brenta. Suoli e 
paesaggi. Museo Tridentino di Scienze Naturali, Monografie 2, Trento: 239 pp. (in Italian).

Seeber J., Seeber, G.U.H., 2005. Effects of land-use changes on humus forms on alpine pastureland (Central Alps., Tyrol). Geoderma 124: 215-222.

Shang C., Tiessen H., 2003. Soil organic C sequestration and stabilization in karstic soils of Yucatan. Biogeochemistry 62: 177-196.

Skiba S., 1995. Soils of the upper timberline ecotone in the Polish Carpathian Mts. Prace Geograficzne 98: 189-198.

Smal H., Olszewska M., 2008. The effect of afforestation with Scots pine (Pinus silvestris L.) of sandy post-arable soils on their selected properties. II. Reaction, carbon, nitrogen and phosphorus. Plant and Soil 305: 171-187.

Tarnocai C.J., Canadell G., Schuur E.A.G., Kuhry P., Mazhitova G., Zimov S., 2009. Soil organic carbon pools in the northern circumpolar permafrost region, Global Biogeochemical Cycles 23: DOI:10.1029/2008GB003327.

Tejada M., Hernandez M.T., Garcia C., 2006. Application of two organic amendments on soil restoration: effects on the soil biological properties. Journal of Environmental Quality 35: 1010-1017.

Vacca A., Serra G., Scalenghe R., 2017. Vegetation, soils, and humus forms of Sardinian holm oak forests and approximated cross-harmonization of vegetation types, WRB soil groups and humus forms in selected Mediterranean ecosystems. Applied Soil Ecology: DOI: 10.1016/j.apso il.2017.06.024.

Vesterdal L., Clarke N., Sigurdsson B.D., Gundersen P., 2013. Do tree species influence soil carbon stocks in temperate and boreal forests? Forest Ecology and Management 309: 4-18.

Wasak K., 2013. Application of selected classification systems in describing the types of humus in forest soils of the Tatra Mountains. Prace Geograficzne 135: 101-119.

Wasak K., 2014. Cellulose decomposition rate and features of organic matter in forest soils in the Tatra Mountains. Gruntoznavstvo 15: 70-80.

Wasak K., 2017. The effect of parent material and vegetation on the organic matter properties in soils in the lower montane belt in the Tatra. PhD thesis (h). IGiGP Kraków: 182 pp. (manuscript, in Polish)

Wasak K., Drewnik M., 2012. Properties of humus horizons of soils developed in the lower montane belt in the Tatra mountains. Polish Journal of Soil Sciences 45: 57-68.
Wasak K., Drewnik M., 2015. Land use effects on soil organic carbon sequestration in calcareous Leptosols in former pastureland - a case study from the Tatra Mountains (Poland). Solid Earth 6: 1103-1115.

Withlington C., Stanford R., 2007. Decomposition rates of buried substrates increase with altitude in the forest-alpine tundra ecotone. Soil Biology and Biochemistry 39: 68-75.

Yang L., Luo P., Wen L., Li D., 2016. Soil organic carbon accumulation during post-agricultural succession in a karst area, southwest China. Scientific Reports 6: DOI:10.1038/srep37118.

Zagórski Z., 1999. Micromorphology and some properties of calcareous soils from Małe Pieniny. Roczniki Gleboznawcze - Soil Science Annual 5 (1-2): 115-126 (in Polish).

Zagórski Z., 2003. Mineralogical and micromorphological indicators of the origin and properties of rendzina soils developed from carbonate rocks of different geological formations. Fundacja „Rozwój SGGW”. Warszawa: 124 pp. (in Polish).

Zaiets O., Poch R.M., 2016. Micromorphology of organic matter and humus in Mediterranean mountain soils. Geoderma 272: 83-72.

Zanella A. Ponge J.-F., Jabiol B., Sartori G., Kolb E., Le Bayon R.-C., Gobat J.-M., Aubert M., De Waal R., Van Delft B., Vacca A., Serra G., Chersich S., Andreetta A., Kölli R., Brun J.J., Cools N., Englisch M., Hager H., Katzensteiner K., Bręthes A., De Nicola Ch., Testi A, Bernier N., Graefe U., Wolf U., Juilleret J., Garlato A., Obber S., Galvan P., Zampedri R., Frizzera L., Tomasi M., Banas D., Bureau F., Tatti D., Salmon S., Menardi R., Fontanella F., Carraro V., Pizzeghello D., Concheri G., Squartini A., Cattaneo D., Scattolin L., Nardi S., Nicolini G., Viola F., 2018a. Humusica 1, article 5: Terrestrial humus systems and forms - Keys of classification of humus systems and forms. Applied Soil Ecology 122: 75-86.

Zanella A., Berg B., Ponge J.-F., Kemmers R.H., 2018b. Humusica 1, article 2: Essential bases-Functional considerations. Applied Soil Ecology 122: 22-41.

Zech W., Wilke B.M., Kögel I., Haider K., Schulten H.R., 1986. Tangelredzina and moderrendzina. Mitteilungen der Deutschen Bodenkundlichen Gesellschaft 46: 23-34.

Zech W., Guggenberger G., 1996. Organic matter dynamics in forest soils of temperate and tropical ecosystems. [In:] Humic Substances in Terrestrial Ecosystems (Piccolo, A., Editor). Elsevier, Amsterdam: 101-107.

Received: April 19, 2018

Accepted: July 3, 2018

Associated editor: A. Lachacz

\section{Sekwestracja węgla organicznego $w$ rędzinach - praca przeglądowa}

Streszczenie: W artykule przedstawiono problematykę zasobu oraz sekwestracji węgla organicznego w glebach zasobnych w węglany, w szczególności w rędzinach, w oparciu o literaturę naukową. Przedstawiono czynniki kształtujące sekwestrację węgla organicznego w rędzinach na tle innych gleb oraz opisano mechanizmy akumulacji materii organicznej charakterystyczne dla tych gleb. Zwrócono uwagę na nietypowość morfologii próchnic występujących w glebach zasobnych w węglany, których specyfika wiąże się z charakterystycznym przebiegiem procesów biologicznych.

Słowa kluczowe: sekwestracja węgla organicznego, rędziny, kalcisole, wapń, magnez 